\title{
Self-Plagiarism dalam Dunia Akademik Ditinjau dari Perspektif Pengaturan Hak Cipta di Indonesia
}

\author{
Hari Sutra Disemadi' ${ }^{1}$, Cindy Kang2) \\ ${ }^{1}$ Fakultas Hukum, Universitas Internasional Batam, Indonesia \\ ${ }^{2}$ Fakultas Hukum, Universitas Internasional Batam, Indonesia \\ Correspondence email: hari@uib.ac.id
}

\begin{abstract}
Abstrak. Banyak sekali kasus plagiarisme yang terjadi di kalangan mahasiswa dan dosen, dan perilaku ini disebabkan oleh banyak faktor. Selain itu, muncul fenomena baru terkait isu plagiarisme, yaitu self-plagiarism, yang telah menimbulkan banyak pro dan kontra di kalangan masyarakat. Penulisan jurnal ilmiah ini menggunakan metode penelitian hukum normatif, berdasarkan peraturanperaturan tertulis dan kepustakaan lain yang mengkaji aspek teori, struktur, serta penjelasan hukum terkait penelitian ini. Kasus selfplagiarism yang terjadi di kalangan akademisi telah menimbulkan banyak pertanyaan di masyarakat mengenai apakah selfplagiarism merupakan pelanggaran hak cipta. Self-plagiarism dapat dianggap sebagai pelanggaran terutama apabila hak cipta dari karya sebelumnya telah dialihkan kepada pihak lain. Hal ini mengakibatkan penulis harus tetap mencantumkan sumber atas karya ilmiah ciptaannya sendiri. Hukum positif di Indonesia tidak banyak yang mengatur mengenai self-plagiarism secara spesifik, namun perilaku self-plagiarism ini termasuk dalam tindakan plagiarisme sehingga bisa ditindaklanjuti melalui jalur hukum, baik pidana maupun administratif, meskipun hukum positif di Indonesia tidak mengatur secara spesifik mengenai self-plagiarism.
\end{abstract}

Kata Kunci: Hukum, Plagiat, Self-Plagiarism, Hak Cipta

\begin{abstract}
There are so many cases of plagiarism that occur among students and lecturers, and this behaviour is caused by many factors. In addition, a new phenomenon has emerged related to the issue of plagiarism, namely self-plagiarism, which has been generated many pros and cons among the society. This scientific journals uses normative legal research methods, based on written regulations and other literature that examines aspects of theory, structure, and legal explanations related to this research. Selfplagiarism cases that occur among academics have raised many questions in the society regarding whether self-plagiarism is a copyright infringement. Self-plagiarism can be considered as violation, especially if the copyright of the previous work has been transferred to another party. This results in writers having to include the source of their own scientific works. There are not many positive laws in Indonesia that specifically regulated self-plagiarism, but the behaviour of self-plagiarism is included in the act of plagiarism so that it can be followed up through legal way, although positive law in Indonesia does not specifically regulate selfplagiarism.
\end{abstract}

Keywords: Law, Plagiarism, Self-Plagiarism, Copyright

\section{PENDAHULUAN}

Kemajuan teknologi pada abad ke-21 telah memberikan dampak yang sangat signifikan, terutama bagi dunia akademik. Teknologi-teknologi yang sudah ada memberikan manfaat yang sangat besar yaitu meningkatkan kualitas pendidikan, meningkatkan minat belajar, serta memudahkan akses informasi bagi dunia pendidikan. Akses informasi yang semakin mudah ini sangat berguna dalam menunjang pembelajaran, tugas, dan penelitian terutama bagi kalangan mahasiswa maupun akademisi (dosen) dalam tingkat Universitas dan Perguruan Tinggi. Banyak dosen memberikan tugas membuat karya tulis ilmiah berbentuk makalah maupun paper kepada mahasiswa sebagai komponen penilaian untuk kelulusan suatu mata kuliah. ${ }^{1}$ Selain itu, dosen selaku akademisi juga memiliki kewajiban untuk melakukan penelitian ilmiah. Kewajiban ini telah diatur dalam Peraturan Menteri Riset, Teknologi, dan Pendidikan Tinggi Republik Indonesia Nomor 44 Tahun 2015 tentang Standar Nasional Pendidikan Tinggi (Permenristek Dikti Nomor 44 Tahun 2015).

Maka dari itu, penulisan karya tulis ilmiah merupakan hal yang lumrah dan sering dilakukan di kalangan mahasiswa dan dosen, dan diharapkan dapat meningkatkan keilmuan dalam bidang masing-masing. Namun, pada prakteknya, banyak mahasiswa dan dosen yang kurang berhati-hati dalam mengolah sumber informasi, sehingga mengakibatkan terjadinya beberapa pelanggaran seperti plagiarisme. Plagiat diartikan sebagai pengambilan karangan (pendapat dan sebagainya) orang lain dan menjadikannya seolah-olah karangan (pendapat dan sebagainya) milik sendiri, misalnya menerbitkan karya tulis orang lain atas nama dirinya sendiri. ${ }^{2}$. Kemudian, Peraturan Menteri Pendidikan Republik Indonesia Nomor 17 Tahun 2010 tentang Pencegahan dan Penanggulangan Plagiat di Perguruan Tinggi menyebutkan bahwa "Plagiat adalah perbuatan sengaja atau tidak disengaja dalam memperoleh kredit atau nilai untuk suatu karya ilmiah, dengan mengutip sebagian atau seluruh karya dan atau karya ilmiah pihak lain yang diakui sebagai

\footnotetext{
${ }^{1}$ Hulman Panjaitan. (2017). Sanksi Pidana Plagiarisme Dalam Hukum Positif Di Indonesia. to-ra, 3(2), 551-557., hlm. 552.

${ }^{2}$ Kamus Besar Bahasa Indonesia. (n.d). Plagiat. https://kbbi.web.id/plagiat, Diakses 20 Januari 2021.
} 
karya ilmiahnya, tanpa menyatakan sumber secara tepat dan memadai”, ketentuan ini termuat dalam Pasal 1 peraturan tersebut.

Jeffrey A Winters selaku Guru Besar Ilmu Politik dari Northwestern University, Chicago, Amerika Serikat, menyatakan bahwa plagiarisme bisa dilakukan secara sengaja maupun tidak sengaja. ${ }^{3}$ Plagiarisme yang dilakukan secara sengaja adalah bahwa jika penulis langsung menjiplak suatu tulisan dan secara sengaja tidak menuliskan sumber atau catatan kaki atas tulisan tersebut. Sedangkan plagiarisme yang dilakukan secara tidak sengaja adalah bahwa jika penulis menulis ide pemikiran milik orang lain, namun terdapat kesalahan dalam mereferensikan ide pemikiran tersebut. ${ }^{4}$ Tindakan plagiarisme memiliki kesamaan fundamental dengan tindakan korupsi, yaitu mengambil sesuatu yang merupakan kepemilikan orang lain secara ilegal. ${ }^{5}$

Teknologi yang semakin berkembang tidak hanya memberikan dampak positif untuk menunjang dunia pendidikan, namun juga memberikan dampak negatif yaitu meningkatkan tingkat plagiarisme dengan mempermudah seseorang untuk menjiplak karya milik orang lain. ${ }^{6}$ Berdasarkan survei yang dilakukan oleh Political and Economic Risk Consultancy (PERC) pada tahun 2010, Indonesia merupakan salah satu negara pelanggar Hak Kekayaan Intelektual (HKI) tertinggi di dunia. ${ }^{7}$ Di Indonesia sendiri telah terdapat undang-undang yang mengatur mengenai plagiarisme, salah satunya adalah Peraturan Menteri Pendidikan Nasional Republik Indonesia Nomor 17 Tahun 2010 tentang Pencegahan dan Penanggulangan Plagiat di Perguruan Tinggi.

Pelaku dari plagiarisme disebut sebagai plagiator. Tindakan plagiarisme ini dapat berupa penjiplakan, pencurian, atau perampokan intelektual karya orang lain dan diakui sebagai karya pribadi. Hal ini tentunya sangat bertentangan dengan nilai dan etika akademik. ${ }^{8}$ Oleh karena itu, pelaku tindakan plagiarisme dalam Perguruan Tinggi dapat diberikan sanksi yang cukup berat untuk mendapatkan efek jera. Tindakan plagiarisme ini juga dapat dikategorikan sebagai pelanggaran Hak Cipta seperti yang sudah diatur dalam Undang-Undang Nomor 28 Tahun 2014 tentang Hak Cipta (UU Hak Cipta).

Di Indonesia, meskipun telah terdapat peraturan perundang-undangan yang mengatur mengenai tindakan plagiarisme, namun tindakan plagiarisme ini masih banyak terjadi di kalangan mahasiswa dan akademisi. Hal ini menunjukkan bahwa masih kurangnya kekuatan hukum dan kepastian hukum mengenai tindakan plagiarisme. Selain dewasa ini, terdapat fenomena baru terkait isu plagiarisme, yaitu self-plagiarism. Self-plagiarism diartikan sebagai tindakan plagiasi dengan cara mengambil karya milik sendiri. ${ }^{9}$ Fenomena ini banyak terjadi di kalangan akademisi, sehingga menimbulkan perdebatan di masyarakat, serta menimbulkan banyak pertanyaan mengenai sah atau tidaknya tindakan self-plagiarism ini di dunia pendidikan. Salah satu isu adanya fenomena tindakan self-plagiarism di Indonesia telah dilakukan oleh Rektor terpilih Universitas Sumatera Utara (USU). Rektor terpilih tersebut diduga telah melakukan self-plagiarism karya ilmiah untuk kenaikan pangkat. Terdapat empat jurnal ilmiah yang dikaitkan dengan unsur plagiarisme. Rektor terpilih tersebut diduga melakukan publikasi ganda pada lebih dari satu media atau jurnal. ${ }^{10}$ Berdasarkan uraian di atas, maka penelitian ini berfokus untuk mengkaji lebih mendalam terkait fenomena selfplagiarism di dunia akademik berdasarkan perspektif UU Hak Cipta. Maka, berdasarkan paparan/uaraian di atas, permasalahan yang diangkat dalam penelitian ini adalah: 1). Apa saja faktor yang mempengaruhi maraknya tindakan plagiarisme di kalangan mahasiswa dan akademisi di Indonesia?; 2). Apakah tindakan self-plagiarism dapat dikategorikan sebagai pelanggaran Hak Kekayaan Intelektual?; dan 3.) Apa saja sanksi yang dapat dikenakan bagi plagiator?.

\section{METODE}

Penelitian ini menggunakan metode penelitian hukum normatif, yakni metode yang berdasarkan peraturanperaturan tertulis dan kepustakaan lain yang mengkaji aspek teori, struktur, serta penjelasan hukum terkait selfplagiarism di Indonesia. Data yang diperoleh dari penelitian ini merupakan data sekunder yang diperoleh dari studi

3 Noviansyah. (2016). Seperempat Esai Mahasiswa Indonesi Terindikasi Plagiat. https://nasional.tempo.co/ $\mathrm{read} / 743504 /$ seperempat-esai-mahasiswa-indonesia-terindikasi-plagiat. Diakses 16 Februari 2021.

${ }^{4}$ Ibid.

5 Suryana Ermis. (2016). Self Efficacy Dan Plagiarisme Di Perguruan Tinggi. Tadrib, 2(2), 214-237., hlm. 216.

6 Jufrina Rizal. (2010). Plagiarisme Akademik: Perspektif Metode Keilmuan dan Doktrin Hukum. Jurnal Hukum \& Pembangunan, 40(3), 339-363., hlm. 351.

${ }^{7}$ Hulman Panjaitan. (2017). Op.Cit.

8 Suryana Ermis. (2016). Op.Cit.

9 Thariq Bintoro. (2020). Ini 5 Hal Seputar Self-Plagiarism, Plagiasi Karya Sendiri Emang Salah?. https://www.idntimes.com/life/education/thariq-bintoro/self-plagiarisme-c1c2/5. Diakses 2 Februari 2020.

10 Kumparan. (2020). Membedah Self-Plagiarism, Isu yang Menempa Rektor Terpilih USU. https://kumparan.com/kumparannews/membedah-self-plagiarism-isu-yang-menerpa-rektor-terpilih-usu-1uo5agM4jUr/full.

Diakses 17 Februari 2020. 
kepustakaan. Data tesebut berupa peraturan perundang-undangan yang berkaitan dengan objek penelitian seperti UU Hak Cipta dan Undang-Undang Nomor 20 Tahun 2003 tentang Sistem Pendidikan Nasional yang kemudian dianalisis menggunakan teknik analisis deskriptif-kualitatif.

\section{HASIL DAN PEMBAHASAN}

\section{Faktor-Faktor yang Mempengaruhi terjadinya Tindakan Plagiarisme}

Buku yang berjudul "Sebuah Pengantar Penulisan Ilmiah" menegaskan bahwa terdapat beberapa hal yang dapat dikategorikan sebagai tindakan plagiarisme, yaitu mengakui tulisan, gagasan, temuan, karya milik orang lain sebagai kepunyaan atau milik sendiri, serta menulis, meringkas, dan memparafrasekan suatu tulisan tanpa mencantumkan sumbernya. ${ }^{11}$ Kemudian, menurut Sastroasmoro, plagiarisme dapat diklasifikasikan menjadi beberapa jenis, berdasarkan aspek yang dicuri, motif kesengajaan, proporsi persentase kata yang dicuri, serta pola plagiarisme. Penjelasan dan klasifikasinya adalah sebagai berikut: ${ }^{12}$

Berdasarkan aspek yang dicuri, plagiarisme terbagi atas plagiarisme ide; plagiarisme isi; plagiarisme kata, kalimat, paragraf; dan plagiarisme total. Plagiarisme jenis ini merupakan jenis yang dianggap memiliki sanksi paling berat. Berdasarkan motif, plagiarisme terbagi atas plagiarisme secara sengaja; dan plagiarisme secara tidak disengaja. Berdasarkan proporsi persentase kata yang dicuri, plagiarisme terbagi atas plagiarisme ringan, yaitu plagiarisme dengan persentase di bawah 30\%; plagiarisme sedang, yaitu plagiarisme dengan persentase sekitar 30\% hingga 70\%; dan plagiarisme berat atau total, yaitu plagiarisme dengan persentase di atas $70 \%$. Berdasarkan pola, plagiarisme terbagi atas plagiarisme kata demi kata; dan plagiarisme mozaik, yaitu penggabungan ide orisinil dengan ide milik orang lain.

Terdapat beberapa hal yang tidak termasuk dalam tindakan plagiarisme dalam menulis dan mengutip suatu tulisan, yaitu apabila penulis menggunakan informasi yang merupakan fakta umum, memparafrase suatu tulisan dengan sumber yang jelas, serta mengutip secukupnya tulisan milik orang lain. Dalam menulis suatu karya ilmiah, proporsi ide dan gagasan penulis harus dominan dibandingkan dengan jumlah kutipan yang diambil dari sumber lain. Apabila proporsi sumber tulisan lain lebih dominan, maka suatu karya dapat dianggap tidak orisinil. ${ }^{13}$

Maraknya tindakan plagiarisme yang dilakukan di kalangan mahasiswa dan akademisi membuat banyak masyarakat yang menganggap ini adalah hal yang lumrah dan bukan merupakan pelanggaran. Padahal, tindakan plagiarisme dalam dunia akademis sangat bertentangan dengan nilai-nilai dan etika intelektual, serta mencoreng nama baik dunia pendidikan. Terdapat banyak faktor yang menyebabkan tindakan plagiarisme banyak terjadi di kalangan mahasiswa dan akademisi, yaitu:

a. Kurangnya edukasi mengenai Hak Kekayaan Intelektual (HKI) di kalangan masyarakat sehingga masyarakat beranggapan bahwa suatu karya yang beredar di internet merupakan public domain sehingga tidak memerlukan citasi $^{14}$;

b. Ketidaksengajaan dan keteledoran sehingga penulis yang melakukan plagiarisme tidak menyadari bahwa ia sedang melakukan plagiarisme. Contohnya adalah saat seorang penulis lupa menuliskan men-citasi dan menuliskan sumber pada tulisannya;

c. Ketidaktahuan seorang penulis mengenai tata cara dan kaidah-kaidah penulisan karya ilmiah yang baik;

d. Adanya fasilitas internet yang mempermudah penelusuran sebuah informasi;

e. Kurang sosialisasi mengenai tata cara dan kaidah-kaidah penulisan karya ilmiah yang baik;

f. Kurang sosialisasi mengenai plagiarisme serta sanksi-sanksi yang dapat diperoleh;

g. Ketidakjujuran;

h. Rasa malas yang mengakibatkan seseorang mengambil jalan pintas tanpa memperhatikan kualitas;

i. Banyaknya masyarakat yang menganggap bahwa plagiarisme hanyalah pelanggaran etika dan bukan pelanggaran hukum, sehingga tidak menganggap serius dampak yang ditimbulkan dari perilaku plagiarisme ini;

j. Kurangnya kemampuan dan kompetensi (self-efficacy) seseorang dalam mencapai tujuan ataupun melakukan tugas dan mengatasi hambatan, sehingga cenderung mengambil jalan pintas ${ }^{15}$;

k. Kurangnya pengawasan dari berbagai pihak dalam civitas akademika, serta ketidaktegasan institusi berwenang serta aparat hukum dalam menindaklanjuti tindakan plagiarisme;

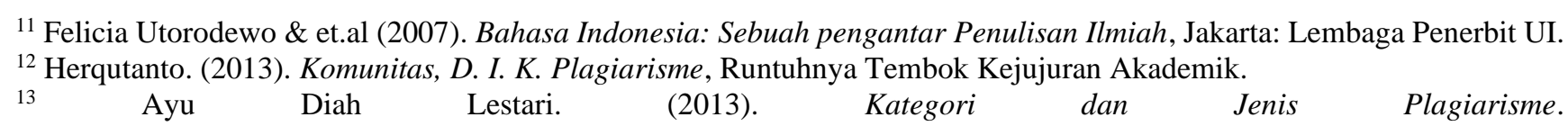
https://www.kompasiana.com/diahayulhs/5529b26df17e61721ad623c6/kategori-dan-jenis-

plagiarisme\#: :text=Sastroasmoro\%20(2007)\%20menjabarkan\%20kategori\%20plagiarisme,plagiarisme\%20tulisan\%2C\%20dan \%20plagiarisme\%20total. diakses pada 17 Februari 2021.

${ }^{14}$ Jufrina Rizal. (2010). Op.Cit.

${ }^{15}$ Suryana Ermis. (2016). Op.Cit. 
1. Tekanan yang dialami oleh mahasiswa maupun akademisi dalam melakukan suatu tugas atau penelitian yang mengakibatkan timbulnya rasa takut untuk gagal. Hal ini dipengaruhi oleh budaya sistem pendidikan nasional Indonesia yang mengukur sebuah keberhasilan dari hasil akhir dan tidak memandang proses yang dilalui, sehingga banyak orang yang cenderung mengambil jalan pintas ${ }^{16}$; dan

m. Banyaknya akademisi yang masih belum memahami batasan-batasan dalam plagiarisme. Hal ini disebabkan oleh ketidaktahuan yang berujung ketidaksengajaan. ${ }^{17}$

\section{Fenomena Self-Plagiarism yang Terjadi di Kalangan Akademisi}

Dunia pendidikan terutama di kalangan Universitas dan Perguruan Tinggi saat ini tengah dihebohkan dengan kasus self-plagiarism yang diduga dilakukan oleh, Rektor Terpilih Universitas Sumatera Utara (USU). ${ }^{18}$ Fenomena selfplagiarism yang terjadi telah menimbulkan banyak pro dan kontra di kalangan akademisi. Pengertian dari selfplagiarism adalah tindakan plagiasi dengan cara mengambil karya milik sendiri tanpa merujuk karya aslinya. ${ }^{19}$ Banyak penulis yang meyakini bahwa tidak masalah jika menulis ulang sebuah karya menggunakan tulisan milik sendiri sebelumnya tanpa menuliskan sumber, karena tidak menyalin karya milik orang lain.

Terdapat tiga jenis self-plagiarism, yaitu Text Recycling, Redundant and Duplicate Publication, dan Salamislicing/Data Fragmentation.$^{20}$ Adapaun penjelasan dari 3 jenis self-plagiarism tersebut adalah sebagai berikut: Pertama, Text Recycling adalah saat seorang penulis menggunakan tulisan sebelumnya atau tulisan miliknya yang belum publish untuk tujuan yang baru. Dalam hal ini, text recycling tidak dapat dianggap sebagai tindakan plagiarisme apabila naskah tulisan tersebut merupakan dokumen internal dan tidak terpublikasi (tidak ada lisensi penerbit), misalnya adalah tugas akhir berupa skripsi, tesis, atau disertasi yang belum dipublikasikan, atau proposal, makalah untuk keperluan presentasi dan konferensi, dan sebagainya. ${ }^{21}$ Menurut Cary Moskovitz dalam tulisannya yang berjudul 'Text Recycling in Scientific Writing', text recycling atau daur-ulang teks adalah penggunaan kembali materi tekstual (prosa, visual, atau persamaan) dalam dokumen baru, dimana dokumen tersebut: a.) identik dengan sumber sebelumnya secara substansial; b.) tidak mencantumkan kutipan sumber materi yang disajikan; dan c.) penulis juga merupakan penulis dari dokumen yang digunakan sebagai sumber. ${ }^{22}$ Maka, dalam beberapa konteks, text recycling bersifat etis, legal, dan bahkan dibutuhkan untuk menyampaikan sebuah gagasan. Namun, dalam situasi tertentu, text recycling dapat dinyatakan bersifat tidak etis, tidak profesional, dan bahkan melanggar hak cipta.

Kedua, Redundant and Duplicate Publication adalah saat seorang penulis mempublikasikan suatu tulisan yang sama di beberapa tempat yang berbeda tanpa memberitahukan kepada pihak penerbit. Faktor penyebab terjadinya tindakan ini adalah karena ketidaktahuan penulis mengenai etika publikasi. ${ }^{23}$ Menurut Enago Academy, istilah duplicate publication atau redundant mengacu pada naskah yang dikirimkan oleh penulis ke lebih dari satu jurnal. Hal ini juga mengacu kepada tumpang tindih dalam konten dan kepengarangan dari karya yang diterbitkan sebelumnya. Dalam hal ini, konten duplicate publication yang diterbitkan dapat dipastikan identik dan setidaknya memiliki satu penulis yang sama. Dalam kebanyakan kasus, ini akan dianggap sebagai kesalahan akademis dan pelanggaran, namun, ada kondisi tertentu dimana duplicate publication tidak dianggap sebagai pelanggaran, contohnya adalah saat BioMed Central mendukung rekomendasi dari Komite Internasional Editor Jurnal Medis dan mengizinkan duplicate publication dengan beberapa pengecualian. Terkait perilaku duplicate publication, penulis mungkin memiliki alasan pribadi sehingga melakukan tindakan ini, misalnya karena tekanan untuk menerbitkan jurnal guna memajukan karir akademisnya, atau penulis merasa bahwa dengan menerbitkan sebuah tulisan di beberapa tempat yang berbeda dapat mempercepat proses publikasi apabila tulisan diterima oleh salah satu pihak penerbit. ${ }^{24}$ Maka, tindakan ini tidak dapat diterima karena mengakibatkan resiko 'data miring', hasil yang tidak bisa dikonfirmasi, dan self-plagiarism. Selain itu, tindakan ini juga dapat menambah beban yang seharusnya tidak perlu bagi para staff penerbit karena membuang waktu dan tenaga dalam me-review suatu tulisan/karya ilmiah.

\footnotetext{
${ }^{16} \mathrm{Ibid}$

${ }^{17}$ Muhammad Abdan Shadiqi. (2019). Memahami dan Mencegah Perilaku Plagiarisme dalam Menulis Karya Ilmiah. Buletin Psikologi, 27(1), 30-42., hlm. 36.

${ }^{18}$ Kumparan. (2020). Op.Cit.

${ }^{19}$ Thariq Bintoro. (2020). Op.Cit.

${ }^{20}$ Muhammad Abdan Shadiqi. (2019). Op.Cit.

${ }^{21}$ Ibid

${ }^{22}$ Cary Moskovitz. (2019). Text recycling in scientific writing. Science and engineering ethics, 25(3), 813-851., hlm. 820.

${ }^{23}$ Muhammad Abdan Shadiqi. (2019). Op.Cit.

24 Enago Academy. (2020). Learn About Redundant (Duplicate) Publications and Simultaneous Submissions. https://www.enago.com/academy/learn-redundant-duplicate-publications-simultaneous-submissions/. Diakses 18 Februari 2021.
} 
Ketiga, Salami-slicing/Data Fragmentation adalah saat penulis memecah studi ke beberapa publikasi. Tidak seperti duplicate publication yang melibatkan satu tulisan yang sama dalam dua atau lebih publikasi, salami-slicing membagi suatu studi besar menjadi dua atau lebih publikasi. Sebagai aturan umum, selama 'irisan' atau pembagian dari studi tersebut berisikan hipotesis dan metode yang sama, maka ini termasuk dalam kategori self-plagiarism. 'Irisan' yang sama seharusnya tidak boleh dipublikasikan lebih dari sekali. ${ }^{25}$ Menurut U.S Office of Research Integrity, salamislicing bisa mengakibatkan distorsi literatur dengan membuat para pembaca berpikir bahwa data yang disajikan dalam setiap pembagian tulisan tersebut (contohnya: jurnal artikel) merupakan turunan dari sampel subjek yang berbeda. Hal ini tidak hanya 'membelokkan' data base ilmiah, namun juga membuang waktu dan tenaga para pembaca serta editor dan reviewer yang harus membaca setiap pembagian tulisan satu per satu secara terpisah. Hal ini juga tidak adil bagi citation record penulis yang melakukan salami-slicing. ${ }^{26}$ Maka, seorang penulis harus bisa memperhatikan batasanbatasan dalam salami-slicing karena terdapat beberapa hal yang tidak termasuk kategori salami-slicing, contohnya adalah apabila pembagian tulisan tersebut menjelaskan variabel yang berbeda.

Eksistensi self-plagiarism di Indonesia, hingga saat ini masih menuai pro dan kontra terutama di kalangan akademisi. Beberapa ahli berpendapat bahwa istilah self-plagiarism tidak tepat karena tidak ada pihak manapun yang dicurangi dalam penggunaan kembali karya milik sendiri, seperti yang diungkapkan oleh Stephanie J Bird, penulis SelfPlagiarism and Dual Redundant Publications: What is the Problem? ${ }^{27}$ Terdapat pula beberapa ahli yang berpendapat bahwa istilah self-plagiarism adalah istilah yang tepat, karena walaupun tidak terdapat unsur pencurian karya intelektual, namun terdapat unsur kecurangan dan ketidakjujuran yang dapat merugikan berbagai pihak, seperti yang diungkapkan oleh David B. Resnik, ahli Bioetika dari National Institutes of Health ${ }^{28}$ Banyak pula yang beranggapan bahwa perilaku self-plagiarism ini tidak merugikan orang lain dan tidak mengambil tulisan milik orang lain, sehingga tidak bisa dianggap sebagai tindakan plagiarisme. ${ }^{29}$

The Journal of International Business Studies (JIBS) dengan tegas telah memasukkan self-plagiarism sebagai pelanggaran dalam kode etik penulisan karya ilmiah. Namun, The American Political Science Association (APSA) hanya menyinggung mengenai plagiarisme dan tidak menyinggung mengenai self-plagiarism. Pada tahun 2008, A Guide to Professional Ethics in Political Science yang diterbitkan oleh APSA menyatakan bahwa penulis boleh mengirim naskah karya ilmiah kepada lebih dari satu jurnal profesional, dengan syarat harus melaporkan terlebih dahulu kepada editor. ${ }^{30}$ Kemudian pihak sebuah program dan software layanan deteksi plagiarisme yang berbasis Internet yaitu turnitin.com, menegaskan self-plagiarism merupakan bagian dari tindakan plagiarisme karena menggunakan kembali kata-kata milik sendiri dan merepresentasikannya sebagai baru adalah bentuk dari ketidakjujuran. Sangat mudah untuk mengabaikan perilaku self-plagiarism karena ketika peneliti merupakan penulisnya, mereka cenderung berargumen bahwa mereka dapat menggunakan kata-kata yang mereka buat sendiri dan hal tersebut bukanlah pencurian karya intelektual. Namun, self-plagiarism tetaplah merupakan ketidakjujuran akademis, dan dapat melanggar hak cipta penerbit. ${ }^{31}$

Studi yang dilakukan oleh Committee on Publication Ethics (COPE) pada tahun 2019 tentang etika publikasi juga telah menyebutkan bahwa self-plagiarism merupakan salah satu perhatian terbesar bagi penerbit. Dari survei yang dilakukan terhadap 656 editor jurnal akademis, ditemukan bahwa separuh dari responden pernah melakukan selfplagiarism. COPE juga menyatakan bahwa self-plagiarism ini akan menjadi masalah utama terkait etika publikasi dalam 5 (lima) tahun ke depan. ${ }^{32}$

Di Indonesia, pengaturan mengenai plagiarisme telah diatur dalam Permendiknas Nomor 17 Tahun 2012 tentang Pencegahan dan Penanggulangan Plagiat di Perguruan Tinggi, namun tidak secara spesifik mengatur mengenai selfplagiarism. Seperti yang telah disinggung sebelumnya, self-plagiarism termasuk dalam kegiatan plagiarisme, oleh karena itu, Permendiknas Nomor 17 Tahun 2012 ini juga dapat dijadikan acuan hukum dalam menangani kasus plagiarisme. Selain itu, terdapat pula Peraturan Kepala Lembaga Ilmu Pengetahuan Indonesia (LIPI) Nomor 5 Tahun

${ }^{25}$ Muhammad Abdan Shadiqi. (2019). Op.Cit.

26 Elsevier. (2012). Factsheet: Salami-slicing. https://www.elsevier.com/_data/assets/pdf_file/0011/653888/SalamiSlicing-factsheet-March-2019.pdf, Diakses 11 Februari 2021.
$27 \quad$ Muhadjir
Effendy.
(2013).
Self-Plagiarism
atau
Auto
Plagiat.

https://regional.kompas.com/read/2013/04/09/02534328/.Self-Plagiarism.atau.Auto-

Plagiat\#: :text=Ensiklopedia\%20elektronik\%20Wikipedia\%20menulis\%2C\%20self,atau\%20tanpa\%20merujuk\%20karya\%20asli nya. Diakses 18 Februari 2021.

${ }^{28}$ Ibid.

${ }^{29}$ Thariq Bintoro. (2020). Op.Cit.

${ }^{30}$ Muhadjir Effendy. (2013). Op.Cit.

${ }^{31}$ Arumugam \& Aldhafiri. (2016). What is the Impact of Self-Plagiarism for Researchers?”. www.turnitin.com/blog/whatis-the-impact-of-self-plagiarism-for-researchers. Diakses 20 Februari 2021.

${ }^{32}$ COPE. (2019). Exploring publication ethics in the arts, humanities, and social sciences: A COPE study 2019|COPE: Committee on Publication Ethics, https://publicationethics.org/node/44481, Diakses 20 Februari 2021. 
2014 tentang Kode Etik Publikasi Ilmiah. Kode etik ini dapat dijadikan acuan dalam menuliskan suatu karya ilmiah, serta dalam memeriksa suatu karya ilmiah. Pasal 1 Angka 2 Peraturan Kepala LIPI Tentang Kode Etik Publikasi Ilmiah menyebutkan bahwa "Kode Etika Peneliti adalah acuan moral yang berlaku secara nasional bagi peneliti di unit penelitian dan pengembangan (litbang) dalam melaksanakan penelitian dan mempublikasikan hasil penelitian untuk pengembangan ilmu pengetahuan dan teknologi bagi kemanusiaan." Kode Etik ini bertujuan untuk meningkatkan mutu jurnal ilmiah serta dapat dijadikan acuan bagi para pengelola jurnal ilmiah dalam memeriksa suatu karya ilmiah.

Pada Bab IV Tentang Kode Etika Mitra Bestari Jurnal Ilmiah di bagian 4.2.3 mengatur bahwa "menjamin prinsip kebenaran, kebaruan, dan keaslian; mengutamakan manfaat karya tulis bagi perkembangan ilmu pengetahuan, teknologi dan inovasi; serta memahami dampak tulisan terhadap pengembangan ilmu pengetahuan." Maka dari itu, penulis harus menjamin kebaruan tulisan yang telah dibuat dan tidak boleh melakukan self-plagiarism. Selain itu, pada Bab IV Peraturan Kepala LIPI Tentang Kode Etik Publikasi Ilmiah di bagian 5.2.1 juga menyatakan bahwa penulis harus membuat pernyataan yang menyatakan bahwa karya tulis yang ia hasilkan adalah asli, belum pernah dipublikasikan sebelumnya dalam bahasa apapun dan sedang tidak dalam proses pengajuan ke penerbit lain. Terdapat pula beberapa peraturan perundang-undangan lainnya yang mengatur mengenai plagiat dan self-plagiariasm, yaitu Surat Dirjen Dikti No. 1311/D/C/2010 tentang Pencegahan dan Penanggulangan Plagiat, Surat Dirjen Dikti No. 190/D/T/2011 tentang Validasi Karya Ilmiah, dan Surat Dirjen Dikti No. 3298 tentang Upaya Pencegahan Tindakan Plagiat.

Apabila ditinjau dari perspektif UU Hak Cipta, perbuatan plagiarisme terhadap karya tulis ilmiah dapat dipidanakan, hal ini diatur dalam Pasal 112 hingga Pasal 120 UU Hak Cipta. Namun, berdasarkan Pasal 44 angka 1 UU Hak Cipta ditegaskan bahwa "penggunaan, pengambilan, penggandaan, dan/atau pengubahan suatu ciptaan dan/atau produk hak terkait secara seluruh atau sebagian yang substansial tidak dianggap sebagai pelanggaran Hak Cipta jika sumbernya disebutkan atau dicantumkan secara lengkap untuk keperluan pendidikan, penelitian, penulisan karya ilmiah, penyusunan laporan, penulisan kritik atau tinjauan suatu masalah dengan tidak merugikan kepentingan yang wajar dari Pencipta atau Pemegang Hak Cipta; keperluan keamanan serta penyelenggaraan pemerintahan, legislatif, dan peradilan; keperluan ceramah yang hanya untuk tujuan pendidikan dan ilmu pengetahuan; atau keperluan pertunjukan atau pementasan yang tidak dipungut bayaran dengan ketentuan tidak merugikan kepentingan yang wajar dari Pencipta".

Poin-poin dalam Pasal 44 UU Hak Cipta ini telah dengan jelas mengatur bahwa dalam menggunakan suatu karya milik orang lain, maka wajib mencantumkan sumber secara lengkap dan jelas agar tidak dianggap sebagai pelanggaran Hak Cipta. Perlu ditekankan bahwa hal ini dilakukan guna menghargai dan menghormati hak eksklusif milik Pencipta yang diberikan oleh negara. Hak eksklusif tersebut meliputi hak ekonomi serta hak moral. Hak ekonomi seperti yang tercantum dalam Pasal 8 UU Hak Cipta adalah "hak eksklusif Pencipta atau Pemegang Hak Cipta untuk mendapatkan manfaat ekonomi atas ciptaan." Hak ini meliputi hak bagi para Pencipta atau Pemegang Hak Cipta untuk melaksanakan atau melarang orang lain tanpa persetujuannya untuk membuat, memakai, mengekspor, mengimpor, menjual, maupun mengedarkan suatu ciptaan. ${ }^{33}$ Sedangkan hak moral adalah "hak yang melekat secara abadi pada diri pencipta untuk tetap mencantumkan atau tidak mencantumkan namanya pada salinan sehubungan dengan pemakaian ciptaannya untuk umum; menggunakan nama aslinya atau nama samarannya; mengubah ciptaannya sesuai dengan kepatutan dalam masyarakat; mengubah judul dan anak judul ciptaan; dan mempertahankan haknya dalam hal terjadi distorsi Ciptaan, mutilasi Ciptaan, modifikasi Ciptaan, atau hal lain yang bersifat merugikan kehormatan dirinya atau reputasinya", ketentuan ini diatur dalam Pasal 5 UU Hak Cipta. Maka dari itu, tindakan mengambil karya/ciptaan seperti karya tulis ilmiah sendiri maupun orang lain adalah sah atau diakui apabila menyebutkan sumbernya. Hal ini sesuai dengan Pasal 44 angka 1 UU Hak Cipta menegaskan bahwa tidak dianggap sebagai pelanggaran Hak Cipta jika sumbernya disebutkan atau dicantumkan secara lengkap untuk keperluan pendidikan, penelitian, penulisan karya ilmiah.

Kemudian, Pasal 112 hingga Pasal 119 UU Hak Cipta mengatur mengenai tindak pidana atas berbagai jenis pelanggaran hak cipta, namun tidak secara spesifik menyebutkan mengenai plagiarisme ataupun self-plagiarism. Meskipun tidak secara eksplisit menyebutkan mengenai tindakan plagiarisme atau self-plagiarism, namun mengambil karya/ciptaan milik seseorang tanpa mencantumkan sumber dengan jelas (atau bisa disebut dengan tindakan plagiarisme atau self-plagiarism) tetap dapat dianggap sebagai pelanggaran Hak Cipta karena telah melanggar hak eksklusif yang diberikan kepada pencipta/pemegang Hak Cipta.

Banyak pihak yang beranggapan bahwa tindakan self-plagiarism tidak melanggar Hak Cipta, baik secara hak ekonomi maupun hak moral, karena tulisan yang diambil merupakan tulisan miliknya sendiri sehingga tidak perlu mencantumkan sumber. ${ }^{34}$ Namun, mengingat bahwa suatu ciptaan dapat dialihkan atau di-lisensi-kan kepada pihak lain seperti yang diatur dalam Pasal 80 hingga Pasal 86 UU Hak Cipta, maka self-plagiarism juga dapat dianggap sebagai pelanggaran kode etik terutama apabila hak cipta dari karya sebelumnya telah dialihkan kepada pihak lain. Seringkali

33 Hari Sutra Disemadi \& Cindy Kang. (2020). Tantangan Penegakan Hukum Hak Kekayaan Intelektual dalam Pengembangan Ekonomi Kreatif di Era Revolusi Industri 4.0. Jurnal Komunikasi Hukum (JKH), 7(1), 54-71., hlm. 56.

${ }^{34}$ Anisah Hasan, Irwan Akib \& Mas'ud Ibrahim. (2016). Fenomena Plagiarisme Mahasiswa. Jurnal Equilibrium Pendidikan Sosiologi, 4(1), 20-29., hlm. 28. 
hak cipta atas suatu artikel jurnal ilmiah dipegang oleh pihak penerbit dan bukan dipegang oleh penulis, oleh karena itu, meskipun karya ilmiah tersebut adalah milik seorang penulis, penulis tersebut harus tetap mencantumkan sumber atas ciptaannya sendiri.

\section{Sanksi yang Dapat Dikenakan bagi Pelaku self-plagiarism}

Banyak orang yang bergerak di bidang pendidikan beranggapan bahwa plagiarisme atau self- plagiarism merupakan salah satu perbuatan yang tidak dapat diterima karena telah melanggar etika dan kaidah dalam dunia pendidikan. Perilaku plagiarisme merupakan perbuatan yang tidak jujur, penuh kecurangan, dan tidak dapat diampuni. Plagiator dalam lingkungan Perguruan Tinggi biasanya diberikan sanksi yang cukup berat dalam sisi akademis, misalnya skors bagi mahasiswa yang melakukan plagiarisme, ataupun surat teguran atau pemecatan bagi dosen yang melakukan plagiarisme. Apabila ditinjau dari perspektif doktrin hukum, perilaku plagiarisme ini dapat dilihat sebagai pelanggaran hak cipta, persaingan secara tidak sehat, dan pelanggaran moral. ${ }^{35}$. Selain hukuman administratif dari pihak univesitas, hukum positif di Indonesia juga telah mengatur mengenai sanksi bagi para pelaku plagiarisme, baik secara pidana maupun perdata.

Berdasarkan Pasal 380 Kitab Undang-Undang Hukum Pidana (KUHP) menyatakan bahwa: “(1) Diancam dengan pidana penjara paling lama dua tahun delapan bulan atau denda paling banyak lima ribu rupiah: 1) Barang siapa menaruh suatu nama atau tanda secara palsu di atas atau di dalam suatu hasil kesusasteraan, keilmuan, kesenian dan kerajinan atau memalsu nama atau tanda yang asli dengan maksud supaya karenanya orang mengira bahwa itu benar-benar buah hasil orang yang nama atau tandanya olehnya ditaruh di atas atau di dalamnya tadi; dan 2) Barang siapa dengan sengaja menjual, menawarkan, menyerahkan, mempunyai persediaan ke Indonesia, buah hasil kesusasteraan, kesenian, keilmuan, dan kerajinan yang di dalamnya atau di atasnya telah ditaruh nama atau tanda yang palsu atau yang nama dan tandanya yang asli telah dipalsukan seakan-akan itu benar-benar buah hasil orang yang nama atau tandanya telah ditaruh secara palsu tadi; dan (2) Jika buah hasil itu kepunyaan terpidana, boleh dirampas."

Kemudian, apabila self-plagiarism atau plagiarisme yang dilakukan telah melanggar hak ekonomi milik Pencipta/Pemegang Hak Cipta, maka Pasal 113 angka 2 UU Hak Cipta telah menegaskan bahwa "Setiap orang yang dengan atau tanpa izin Pencipta atau Pemegang Hak Cipta melakukan pelanggaran hak ekonomi Pencipta sebagaimana dimaksud dalam Pasal 9 ayat (1) huruf c, huruf d, huruf f, dan/atau huruf h untuk penggunaan secara komersial dipidana dengan pidana penjara paling lama 3 (tiga) tahun dan/atau denda paling banyak Rp 500.000.000 (lima ratus juta rupiah)". UU Hak Cipta juga menyebutkan bahwa tindak pidana tersebut merupakan delik aduan, yang berarti pelaku pelanggaran hak cipta atau dalam hal ini adalah plagiator tidak dapat dituntut kecuali atas pengaduan dari pemegang hak cipta atas karya yang diplagiasi tersebut.

Selanjutnya dalam Pasal 25 Angka 1 Undang-Undang Nomor 20 Tahun 2003 tentang Sistem Pendidikan Nasional (UU Sistem Pendidikan Nasional) menyebutkan bahwa "Perguruan Tinggi menetapkan persyaratan kelulusan untuk mendapatkan gelar akademik, profesi, atau vokasi." Hal ini berarti institusi Perguruan Tinggi memiliki wewenang untuk menetapkan standar kelulusan dan tidak memberikan gelar akademik atau bahkan mencabut gelar akademik kepada plagiator dalam lingkungan Perguruan Tinggi tersebut. Plagiator yang melakukan plagiarisme untuk mendapatkan gelar akademik, profesi, atau vokasi dapat dikenakan sanksi pidana berupa pidana penjara maksimal 2 (dua) tahun dan/atau denda maksimal Rp 200.000.000 (dua ratus juta rupiah) seperti yang telah tertera dalam Pasal 70 UU Sistem Pendidikan Nasional.

Pasal 25 UU Sistem Pendidikan Nasional ini selanjutnya ditindaklanjuti oleh pemerintah dengan mengeluarkan Peraturan Menteri Pendidikan Nasional Republik Indonesia Nomor 17 Tahun 2010 tentang Pencegahan dan Penanggulangan Plagiat di Perguruan Tinggi. ${ }^{36}$ Terdapat beberapa sanksi administratif lainnya bagi plagiator, yaitu: "a) Teguran, peringatan tertulis, penundaan pemberian sebagian hak mahasiswa, pembatalan nilai satu atau beberapa mata kuliah yang diperoleh mahasiswa, pemberhentian dengan hormat dari status sebagai mahasiswa, pemberhentian dengan tidak hormat dari status sebagai mahasiswa, atau pembatalan ijazah apabila mahasiswa telah lulus dari sebuah program", hal ini di atur dalam Pasal 10 Angka 4; dan b) "Teguran, peringatan tertulis, penundaan pemberian hak dosen/peneliti/tenaga kependidikan, penurunan pangkat dan jabatan akademik/fungsional, pencabutan hak untuk diusulkan sebagai guru besar/profesor/ahli peneliti utama bagi yang memenuhi syarat, pemberhentian dengan hormat dari status sebagai dosen/peneliti/tenaga kependidikan, pemberhentian dengan tidak hormat dari status sebagai dosen/peneliti/tenaga kependidikan, atau pembatalan ijazah yang diperoleh dari perguruan tinggi yang bersangkutan", hal ini di atur dalam Pasal 11 Angka 6.

\section{SIMPULAN}

Mahasiswa dan dosen dalam lingkungan Perguruan Tinggi memiliki beban dan kewajiban masing-masing dalam membuat suatu karya ilmiah, baik untuk tugas maupun untuk kewajiban penelitian. Namun, pada prakteknya, banyak

\footnotetext{
${ }^{35}$ Jufrina Rizal. (2010). Op.Cit.

${ }^{36}$ Ibid
} 
mahasiswa dan dosen yang kurang berhati-hati dalam mengolah sumber informasi, sehingga mengakibatkan terjadinya beberapa pelanggaran seperti plagiarisme. Terdapat beberapa faktor yang mengakibatkan seseorang melakukan tindakan plagiarisme, yaitu rasa malas, ketidakjujuran, keteledoran dalam menulis suatu karya ilmiah sehingga penulis cenderung mengambil jalan pintas yaitu memplagiasi karya milik orang lain. Selain itu, kurangnya pengetahuan mengenai HKI dan kurangnya pengetahuan mengenai batasan-batasan dalam penulisan karya ilmiah juga merupakan faktor utama penyebab maraknya perilaku plagiarisme di kalangan akademisi.

Fenomena self-plagiarism dalam dunia pendidikan telah menuai pro dan kontra di masyarakat. Terdapat tiga jenis self plagiarism, yaitu text recycling, redundant/duplicate publication, dan salami-slicing/data fragmentation. Selfplagiarism dapat dianggap sebagai pelanggaran kode etik terutama apabila hak cipta dari karya sebelumnya telah dialihkan kepada pihak lain. Seringkali hak cipta atas suatu artikel jurnal ilmiah dipegang oleh pihak penerbit dan bukan dipegang oleh penulis, oleh karena itu, meskipun karya ilmiah tersebut adalah milik seorang penulis, penulis tersebut harus tetap mencantumkan sumber atas ciptaannya sendiri. Hukum positif di Indonesia tidak banyak yang mengatur mengenai self-plagiarism secara spesifik, namun perilaku self-plagiarism ini termasuk dalam tindakan plagiarisme. Kasus plagiarisme di Indonesia dapat diselesaikan secara pidana dan perdata, baik dikenakan sanksi penjara, denda, maupun administratif.

\section{SARAN}

Terdapat beberapa saran dan tips yang dapat dilakukan agar terhindar dari perilaku plagiarisme, yaitu: 1) Seorang penulis wajib mengutamakan kejujuran dalam mengatasi segala persoalan; 2) Pihak pemerintah terutama Kementerian Pendidikan dan Kebudayaan dapat bekerjasama dengan pihak Institusi Perguruan Tinggi untuk melakukan sosialisasi guna mengedukasi masyarakat termasuk mahasiswa dan dosen mengenai HKI sehingga lebih menghargai hasil karya milik orang lain; 3) Pihak pemerintah terutama Kementerian Pendidikan dan Kebudayaan dapat bekerjasama dengan pihak Institusi Perguruan Tinggi untuk melakukan sosialisasi guna mengedukasi masyarakat termasuk mahasiswa dan dosen mengenai tata cara dan kaidah penulisan karya ilmiah yang baik dan benar; 4) Pihak pemerintah terutama Kementerian Pendidikan dan Kebudayaan serta Institusi Perguruan Tinggi perlu mempertegas penegakan hukum mengenai perilaku plagiarisme baik pidana maupun administratif; 5) Penulis wajib mencantumkan sumber yang jelas dalam menulis suatu karya ilmiah, serta menerapkan teknik parafrase; 6) Penulis dapat memeriksa hasil tulisan karya ilmiah dengan memanfaatkan software cek plagiarisme seperti Turnitin; dan 6) Penulis perlu memahami batasan-batasan dalam plagiarisme, agar terhindar dari self-plagiarism.

\section{DAFTAR PUSTAKA}

Academy, Enago. (2020). Learn About Redundant (Duplicate) Publications and Simultaneous Submissions. https://www.enago.com/academy/learn-redundant-duplicate-publications-simultaneous-submissions/. Diakses 18 Februari 2021.

Arumugam \& Aldhafiri. (2016). What is the Impact of Self-Plagiarism for Researchers?". www.turnitin.com/blog/what-is-the-impact-of-self-plagiarism-for-researchers. Diakses 20 Februari 2021.

Ayu Diah Lestari. (2013). Kategori dan Jenis Plagiarisme. https://www.kompasiana.com/diahayulhs/5529b26df17e61721ad623c6/kategori-dan-jenis-

plagiarisme\#: :text=Sastroasmoro\%20(2007)\%20menjabarkan\%20kategori\%20plagiarisme,plagiarisme\%20tuli san\%2C\%20dan\%20plagiarisme\%20total. diakses pada 17 Februari 2021.

Bintoro, Thariq. (2020). Ini 5 Hal Seputar Self-Plagiarism, Plagiasi Karya Sendiri Emang Salah?. https://www.idntimes.com/life/education/thariq-bintoro/self-plagiarisme-c1c2/5. Diakses 2 Februari 2020.

COPE. (2019). Exploring publication ethics in the arts, humanities, and social sciences: A COPE study 2019|COPE: Committee on Publication Ethics, https://publicationethics.org/node/44481, Diakses 20 Februari 2021.

Disemadi, Hari Sutra., \& Cindy Kang. (2020). Tantangan Penegakan Hukum Hak Kekayaan Intelektual dalam Pengembangan Ekonomi Kreatif di Era Revolusi Industri 4.0. Jurnal Komunikasi Hukum (JKH), 7(1), 54-71.

Elsevier. (2012). Factsheet: Salami-slicing. https://www.elsevier.com/_data/assets/pdf_file/0011/653888/SalamiSlicing-factsheet-March-2019.pdf, Diakses 11 Februari 2021.

Ermis, Suryana. (2016). Self Efficacy Dan Plagiarisme Di Perguruan Tinggi. Tadrib, 2(2), 214-237.

Hasan, Anisah., Irwan Akib \& Mas'ud Ibrahim. (2016). Fenomena Plagiarisme Mahasiswa. Jurnal Equilibrium Pendidikan Sosiologi, 4(1), 20-29.

Herqutanto. (2013). Komunitas, D. I. K. Plagiarisme, Runtuhnya Tembok Kejujuran Akademik.

Kamus Besar Bahasa Indonesia. (n.d). Plagiat. https://kbbi.web.id/plagiat, Diakses 20 Januari 2021.

Kumparan. (2020). Membedah Self-Plagiarism, Isu yang Menempa Rektor Terpilih USU. https://kumparan.com/kumparannews/membedah-self-plagiarism-isu-yang-menerpa-rektor-terpilih-usu1uo5agM4jUr/full. Diakses 17 Februari 2020. 
Hari Sutra Disemadi dan Cindy Kang. Self-Plagiarism dalam Dunia Akademik Ditinjau dari Perspektif Pengaturan Hak Cipta di Indonesia

Moskovitz, Cary. (2019). Text recycling in scientific writing. Science and engineering ethics, 25(3), 813-851.

Muhadjir Effendy. (2013). Self-Plagiarism atau Auto Plagiat. https://regional.kompas.com/read/2013/04/09/02534328/.Self-Plagiarism.atau.Auto-

Plagiat\#: :text=Ensiklopedia\%20elektronik\%20Wikipedia\%20menulis\%2C\%20self,atau\%20tanpa\%20merujuk \%20karya\%20aslinya. Diakses 18 Februari 2021.

Noviansyah. (2016). Seperempat Esai Mahasiswa Indonesi Terindikasi Plagiat. https://nasional.tempo.co/ $\mathrm{read} / 743504 / \mathrm{seperempat-esai-mahasiswa-indonesia-terindikasi-plagiat.} \mathrm{Diakses} 16$ Februari 2021.

Panjaitan, Hulman. (2017). Sanksi Pidana Plagiarisme Dalam Hukum Positif Di Indonesia. to-ra, 3(2), 551-557.

Rizal, Jufrina. (2010). Plagiarisme Akademik: Perspektif Metode Keilmuan dan Doktrin Hukum. Jurnal Hukum \& Pembangunan, 40(3), 339-363.

Shadiqi, Muhammad Abdan. (2019). Memahami dan Mencegah Perilaku Plagiarisme dalam Menulis Karya Ilmiah. Buletin Psikologi, 27(1), 30-42.

Utorodewo, Felicia \& et.al (2007). Bahasa Indonesia: Sebuah pengantar Penulisan Ilmiah, Jakarta: Lembaga Penerbit UI. 